\title{
Evaluation of Turkish Women's Thoughts on Their First Sexual Experience
}

\author{
Gokcen Erdogan ${ }^{1}$ \\ 1. Gynecology and Obstetrics, Near East University Medical Faculty, Nicosia, CYP
}

Corresponding author: Gokcen Erdogan, mdgokcenerdogan@yahoo.com

\section{Abstract \\ Objective}

This study aims to determine the need for sexual health education, whose importance is also emphasized by the World Health Organization, so that the youths can develop a responsible, healthy, and satisfactory sexual life and evaluates Turkish women's thoughts about their first sexual experience.

\section{Methods}

A total of 100 persons who were willing to participate in the research, selected through random sampling from among the women above 18 years of age who have had their first sexual experiences, and applied to the Private Diva Gynecological Diseases and Women's Health Clinic in Cankaya district of Ankara province for gynecological examination, hymen examination, or pregnancy diagnosis from 01/06/2020 to 01/09/2020.

\section{Results}

Of the participants, $63 \%$ were undergraduate students and $47 \%$ had stated that their first sexual experience is a private experience, while $42 \%$ stated that they were not careful about protection during their first sexual experience. It is worth noting that those who were careful about protection were the participants in the age range of $18-25$ (45.5\%). It was seen that $80 \%$ of those who live in the Black Sea Region have not had any sexual activity before their first sexual experience and that $46.7 \%$ of participants who live in this region again were not careful about protection.

\section{Conclusion}

In the link from healthy individuals to a healthy society, sexual education must be started before their first sexual experience and continued throughout life.

Categories: Obstetrics/Gynecology

Keywords: sexuality, first sexual experience, turkish women

Review began 03/11/2021 Review ended 03/22/2021 Published 03/24/2021

\section{() Copyright 2021}

Erdogan. This is an open access article distributed under the terms of the Creative Commons Attribution License CC-BY 4.0., which permits unrestricted use, distribution, and reproduction in any medium, provided the original author and source are credited.

\section{Introduction}

Sexual behaviors and experiences are the sexual behaviors and activities the individuals carry out continuously on their own or together with others, in the form of a habit and as an expression of their sexuality. Since sexuality refers to a multidimensional and combined experience, the points of view on sexuality are rather diversified. Today, it is known that numerous fears related to sexuality, the anxieties about pain, bleeding, strain regarding the first night stem from social myths. In today's society, although sexuality is still taboo and forbidden to talk about from certain perspectives and in certain geographical regions, a certain social segment has adopted a modern point of view, and now sexuality is being discussed within the scope of needs and human rights [1-5].

Since sexuality is an important part of human life and general health, while experiencing it through a healthy pattern affects the individual, family, and society positively, the impairment of sexual health affects the family and society negatively by impairing the individual's physical and psychological health. The protection, improvement, and sustainability of sexual health is possible only by accessing sufficient and correct information, i.e., sexual health education. Family is the institution where the initial sexual information arises and is formed, and it is known that Turkish society has a traditional and conservative structure regarding sexual education, and that talking about sexuality is considered shameful and sinful, and thus forbidden. The children and teenagers who can receive the information they need in neither their families nor systemic and organized education try to obtain such information through informal means, and this effort can result in obtaining harmful, incorrect, or incomplete information, and thus having negative experiences. Among these negative experiences, very grave examples such as premature sexual experiences, addiction to pornography, misogyny, unwanted pregnancies, premature marriages, deliveries and abortions in unhealthy and unsafe environments, sexual function disorders, and maternal and infant mortality can be mentioned [6]. 
When a comprehensive sexual education is planned in compliance with the individual's age, developmental period, and cultural structure, it enables the children and youths to develop behavioral patterns such as displaying healthy physical and emotional development, having positive body image, displaying conscious and logical sexual behaviors, having positive feelings about their own genders, being able to express themselves and their problems regarding sexual matters, telling the sexual behaviors apart as positive and negative ones and protecting themselves from unintended pregnancies, harassment and abuse, and the sexually transmitted diseases [7].

The objective of this study is to learn Turkish women's thoughts about their first sexual experience, determine the educational needs of different groups, and contribute to the body of literature on a subject that is considered culturally taboo and discussed scarcely.

\section{Materials And Methods}

A total of 100 persons who were willing to participate in the research, selected through random sampling from among the women above 18 years of age who have had their first sexual experiences, and applied to the Private Diva Gynecological Diseases and Women's Health Clinic in Cankaya district of Ankara province for gynecological examination, hymen examination, or pregnancy diagnosis from 01.06.2020 to 01.09.2020. Ethics committee permission was obtained before starting the study. The study was conducted in accordance with the ethical principles of the Declaration of Helsinki.

Two different data collection forms have been used in this research.

\section{Socio-demographic data collection form}

The questionnaire prepared to collect information on the participants' age range, geographical regions of origin, educational backgrounds, occupations, marital status, and whether they have an active sexual life.

\section{Questionnaire for the evaluation of thoughts and behaviors regarding the first sexual experience}

The questionnaire was prepared by the researcher to understand the thoughts and behavioral patterns regarding the first sexual experience that results in the breaking of the hymen, which is a conspicuous and social problem according to a review of the relevant scientific literature by the researcher. The questionnaire comprised eight statements and allowed giving replies on a 3-point Likert scale (agree, neither agree nor disagree, disagree).

The following statements were included in this questionnaire:

- I used to have sexual activities before my first sexual experience as well.

- My first sexual partner was someone I had an emotional bond with.

- I had my first sexual experience willingly.

- I'm not against premarital sex.

- My first sexual experience was a planned one.

- I was careful about protection during my first sexual experience.

- My first sexual experience is special to me.

- I had expectations from my first sexual experience.

\section{Statistical analysis}

The data have been analyzed through SPSS 23 software package (IBM Corp, Armonk, NY, USA). While evaluating the study data, the frequency distributions (number, percentage) and the descriptive statistics (average, standard deviation) have been used for the categorical variables and the quantitative variables respectively. The findings have been presented, interpreted, and discussed in tables. In the evaluation of the results, $p \leqslant 0.05$ has been accepted as statistically significant.

\section{Results}

The mean age of the 100 individuals participating in the study was $24.57 \pm 3.88$ years: 66 participants in the 18-15 years age group and 34 participants in the 26-35 years age range. Educational levels were determined as university and above in 72 participants, high school in 22 participants, and primary education in six 
participants. While 58 of the participants stated that they lived in the Central Anatolian region, 15 of them stated that they lived in the Black Sea region, 11 them stated that they lived in the Marmara region, and 16 them stated that they lived in other regions. Forty-two of the participants were students and 58 participants worked. All of them were single and 20 of them had an active sex life.

The answers of the participants regarding their first sexual experience are provided in Figure 1 .

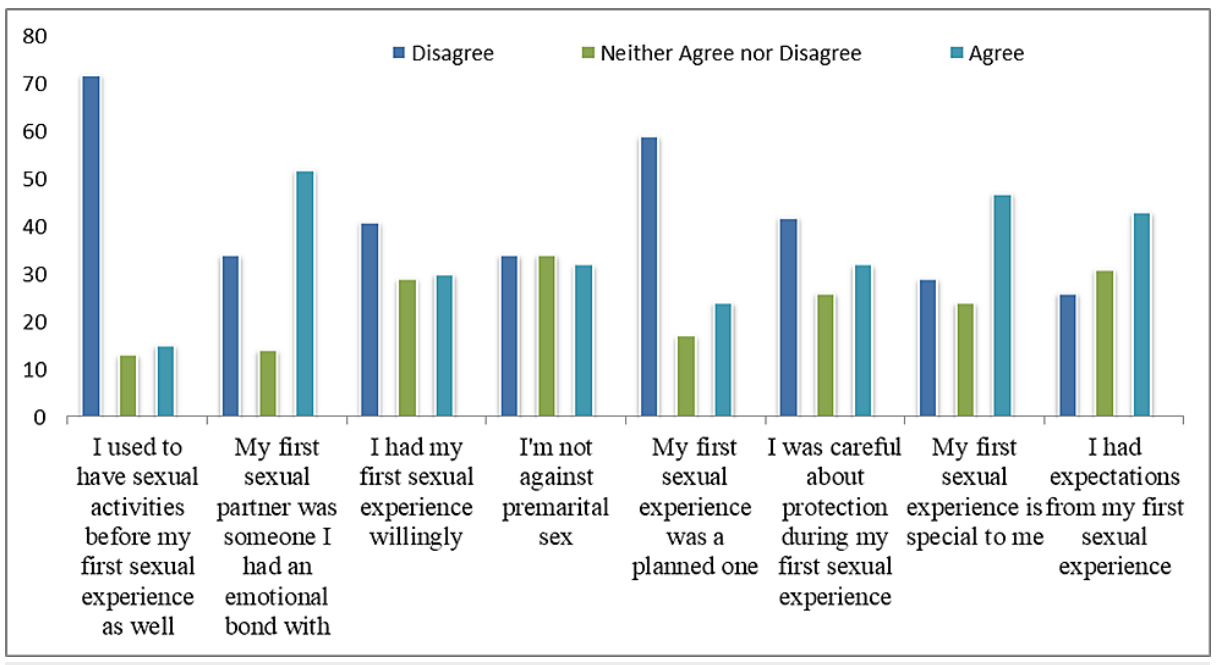

FIGURE 1: Responses of the participants on their first sexual experience

The answers of the participants in the age group 18-25 years to the statements about their first sexual experience are given in Figure 2 and the answers of the participants in the age group 26-35 years are given in Figure 3.

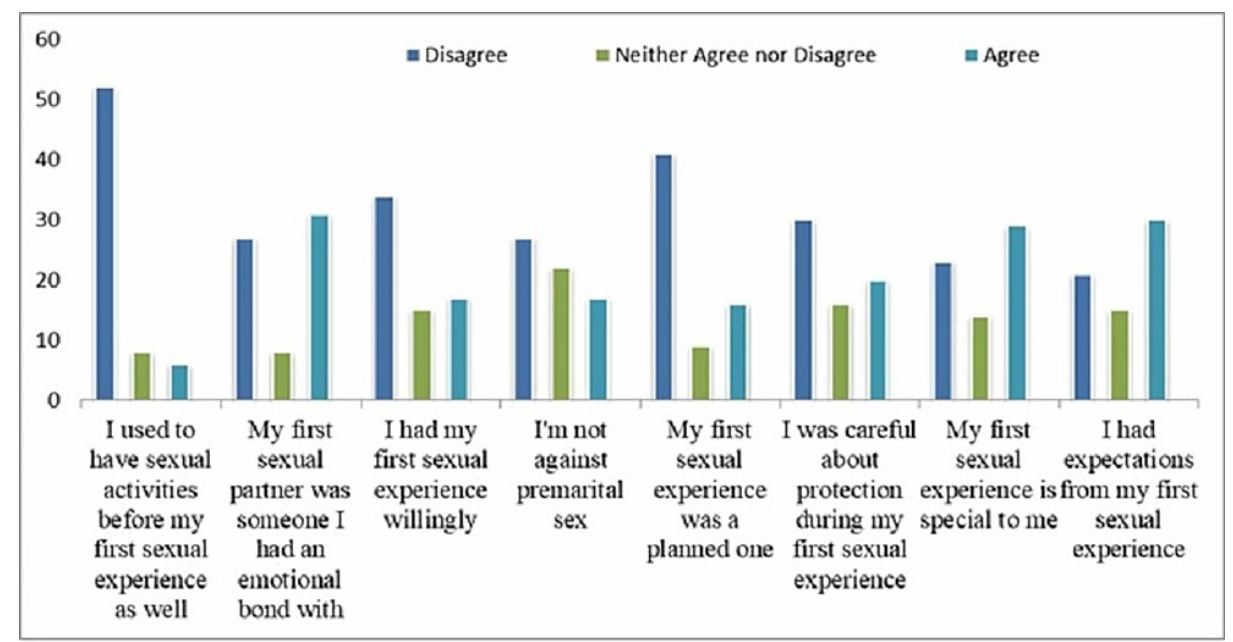

FIGURE 2: Responses of participants in the age group 18-25 years on their first sexual experience 


\section{Cureus}

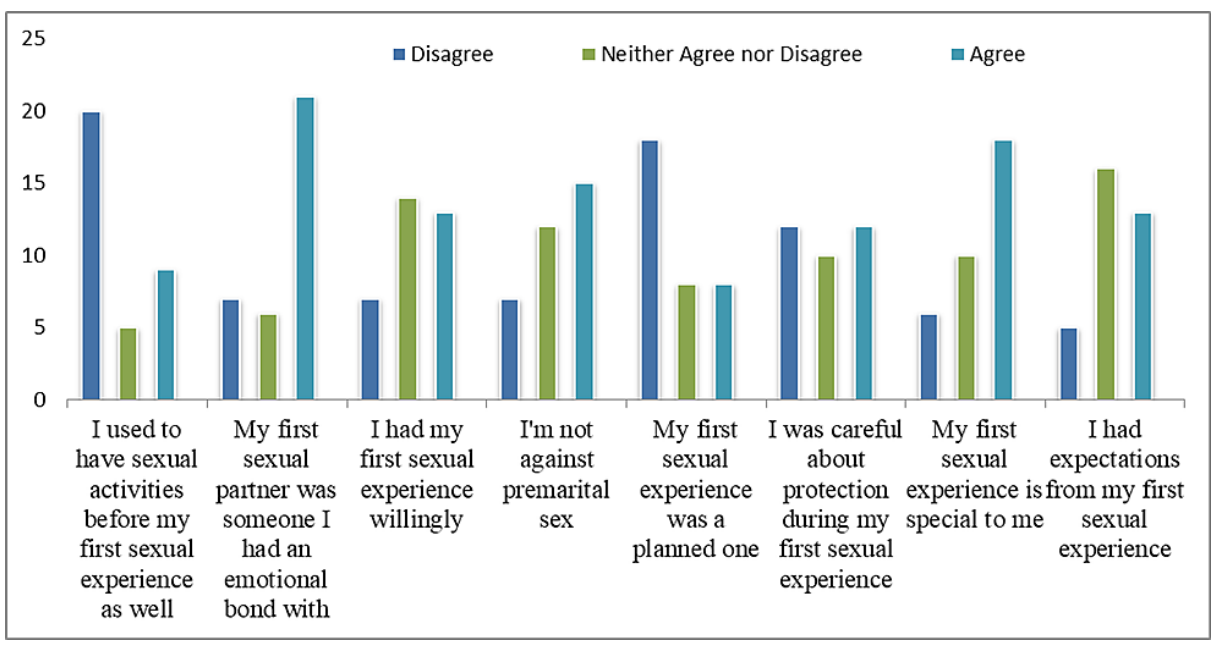

FIGURE 3: Responses of participants in the age group 26-35 years on their first sexual experience

The distribution of the participants according to their educational background in relation to the answers they gave to the statements regarding the first sexual experience is given in Table 1 . 


\section{Cureus}

\begin{tabular}{|c|c|c|c|c|c|}
\hline & & \multicolumn{2}{|c|}{$\begin{array}{l}\text { High School Degree and } \\
\text { Below }\end{array}$} & \multicolumn{2}{|c|}{$\begin{array}{l}\text { Associate's Degree and } \\
\text { Above }\end{array}$} \\
\hline & & $\mathrm{n}$ & $\%$ & $\mathrm{n}$ & $\%$ \\
\hline \multirow{3}{*}{$\begin{array}{l}\text { Tused to have sexual activities before my first sexual } \\
\text { experience as well }\end{array}$} & Disagree & 18 & 64.3 & 54 & 75.0 \\
\hline & $\begin{array}{l}\text { Neither Agree nor } \\
\text { Disagree }\end{array}$ & 4 & 14.3 & 9 & 12.5 \\
\hline & Agree & 6 & 21.4 & 9 & 12.5 \\
\hline \multirow{3}{*}{$\begin{array}{l}\text { My first sexual partner was someone I had an emotional } \\
\text { bond with }\end{array}$} & Disagree & 12 & 42.9 & 22 & 30.6 \\
\hline & $\begin{array}{l}\text { Neither Agree nor } \\
\text { Disagree }\end{array}$ & 5 & 17.9 & 9 & 12.5 \\
\hline & Agree & 11 & 39.3 & 41 & 56.9 \\
\hline \multirow{3}{*}{ I had my first sexual experience willingly } & Disagree & 13 & 46.4 & 28 & 38.9 \\
\hline & $\begin{array}{l}\text { Nelther Agree nor } \\
\text { Disagree }\end{array}$ & 6 & 21.4 & 23 & 31.9 \\
\hline & Agree & 9 & 32.1 & 21 & 29.2 \\
\hline \multirow{3}{*}{ I'm not against premarital sex } & Disagree & 12 & 42.9 & 22 & 30.6 \\
\hline & $\begin{array}{l}\text { Neither Agree nor } \\
\text { Disagree }\end{array}$ & 6 & 27.4 & 28 & 38.9 \\
\hline & Agree & 10 & 35.7 & 22 & 30.6 \\
\hline \multirow{3}{*}{ My first sexual experience was a planned one } & Disagree & 18 & 64.3 & 41 & 56.9 \\
\hline & $\begin{array}{l}\text { Neither Agree nor } \\
\text { Disagree }\end{array}$ & 5 & 17.9 & 12 & 16.7 \\
\hline & Agree & 5 & 17.9 & 19 & 26.4 \\
\hline \multirow{3}{*}{$\begin{array}{l}\text { I was careful about protection during my first sexual } \\
\text { experience }\end{array}$} & Disagree & 15 & 53.6 & 27 & 37.5 \\
\hline & $\begin{array}{l}\text { Neither Agree nor } \\
\text { Disagree }\end{array}$ & 7 & 25.0 & 19 & 26.4 \\
\hline & Agree & 6 & 21.4 & 26 & 36.1 \\
\hline \multirow{3}{*}{ My first sexual experience is special to me } & Disagree & 8 & 28.6 & 21 & 29.2 \\
\hline & $\begin{array}{l}\text { Neither Agree nor } \\
\text { Disagree }\end{array}$ & 10 & 35.7 & 14 & 19.4 \\
\hline & Agree & 10 & 35.7 & 37 & 51.4 \\
\hline \multirow{3}{*}{ I had expectations from my first sexual experience } & Disagree & 10 & 35.7 & 16 & 22.2 \\
\hline & $\begin{array}{l}\text { Neither Agree nor } \\
\text { Disagree }\end{array}$ & 10 & 35.7 & 21 & 29.2 \\
\hline & Agree & 8 & 28.6 & 35 & 48.6 \\
\hline
\end{tabular}

TABLE 1: Distribution of participants by the relation between educational background and replies to statements on first sexual experience

The distribution of the participants by the relationship between the geographical regions and the answers given to the statements about the first sexual experience is provided in Table 2. 


\section{Cureus}

\begin{tabular}{|c|c|c|c|c|c|c|c|c|c|}
\hline & & \multicolumn{2}{|c|}{$\begin{array}{l}\text { Mediterranean/ } \\
\text { Aegean/ Marmara }\end{array}$} & \multicolumn{2}{|c|}{$\begin{array}{l}\text { Central } \\
\text { Anatolia }\end{array}$} & \multicolumn{2}{|c|}{$\begin{array}{l}\text { Black } \\
\text { Sea }\end{array}$} & \multicolumn{2}{|c|}{$\begin{array}{l}\text { Eastern/ } \\
\text { Southeastern } \\
\text { Anatolia }\end{array}$} \\
\hline & & $\mathrm{n}$ & $\%$ & $\mathrm{n}$ & $\%$ & $\mathrm{n}$ & $\%$ & $\mathrm{n}$ & $\%$ \\
\hline \multirow{3}{*}{$\begin{array}{l}\text { I used to have sexual activities before my first } \\
\text { sexual experience as well }\end{array}$} & Disagree & 11 & 57.9 & 44 & 75.9 & 12 & 80.0 & 5 & 62.5 \\
\hline & $\begin{array}{l}\text { Neither Agree nor } \\
\text { Disagree }\end{array}$ & 3 & 158 & 8 & 13.8 & 2 & 13.3 & 0 & 0.0 \\
\hline & Agree & 5 & 26.3 & 6 & 10.3 & 1 & 6.7 & 3 & 37.5 \\
\hline \multirow{3}{*}{$\begin{array}{l}\text { My first sexual partner was someone I had an } \\
\text { emotional bond with }\end{array}$} & Disagree & 3 & 15.8 & 22 & 37.9 & 5 & 33.3 & 4 & 50.0 \\
\hline & $\begin{array}{l}\text { Nelther Agree nor } \\
\text { Disagree }\end{array}$ & 2 & 10.5 & 8 & 13.8 & 3 & 20.0 & 1 & 12.5 \\
\hline & Agree & 14 & 73.7 & 28 & 48.3 & 7 & 46.7 & 3 & 37.5 \\
\hline \multirow{3}{*}{ Thad my first sexual experience willingly } & Disagree & 3 & 15.8 & 27 & 46.6 & 7 & 46.7 & 4 & 50.0 \\
\hline & $\begin{array}{l}\text { Nelther Agree nor } \\
\text { Disagree }\end{array}$ & 6 & 31.6 & 17 & 29.3 & 5 & 33.3 & 1 & 12.5 \\
\hline & Agree & 10 & 52.6 & 14 & 24.1 & 3 & 20.0 & 3 & 37.5 \\
\hline \multirow{3}{*}{ I'm not against premarital sex } & Disagree & 2 & 10.5 & 24 & 41.4 & 5 & 33.3 & 3 & 37.5 \\
\hline & $\begin{array}{l}\text { Neltner Agree nor } \\
\text { Disagree }\end{array}$ & 8 & 42.1 & 19 & 32.8 & 4 & 26.7 & 3 & 37.5 \\
\hline & Agree & 9 & 47.4 & 15 & 25.9 & 6 & 40.0 & 2 & 25.0 \\
\hline \multirow{3}{*}{ My first sexual experience was a planned one } & Disagree & 7 & 36.8 & 37 & 63.8 & 9 & 60.0 & 6 & 75.0 \\
\hline & $\begin{array}{l}\text { Neither Agree nor } \\
\text { Disagree }\end{array}$ & 2 & 10.5 & 9 & 15.5 & 5 & 33.3 & 1 & 12.5 \\
\hline & Agree & 10 & 52.6 & 12 & 20.7 & 1 & 6.7 & 1 & 12.5 \\
\hline \multirow{3}{*}{$\begin{array}{l}\text { I was careful about protection during my first } \\
\text { sexual experience }\end{array}$} & Disagree & 4 & 21.1 & 26 & 44.8 & 7 & 46.7 & 5 & 62.5 \\
\hline & $\begin{array}{l}\text { Nelther Agree nor } \\
\text { Disagree }\end{array}$ & 4 & 21.1 & 18 & 31.0 & 3 & 20.0 & 1 & 12.5 \\
\hline & Agree & 11 & 57.9 & 14 & 24.1 & 5 & 33.3 & 2 & 25.0 \\
\hline \multirow{3}{*}{ My first sexual experience is special to me } & Disagree & 3 & 15.8 & 19 & 32.8 & 4 & 26.7 & 3 & 37.5 \\
\hline & $\begin{array}{l}\text { Neither Agree nor } \\
\text { Disagree }\end{array}$ & 4 & 21.1 & 12 & 20.7 & 6 & 40.0 & 2 & 25.0 \\
\hline & Agree & 12 & 632 & 27 & 46.6 & 5 & 33.3 & 3 & 37.5 \\
\hline \multirow{3}{*}{$\begin{array}{l}\text { I had expectations from my first sexual } \\
\text { experience }\end{array}$} & Disagree & 3 & 15.8 & 15 & 25.9 & 5 & 33.3 & 3 & 37.5 \\
\hline & $\begin{array}{l}\text { Nelther Agree nor } \\
\text { Disagree }\end{array}$ & 7 & 36.8 & 18 & 31.0 & 4 & 26.7 & 2 & 25.0 \\
\hline & Agree & 9 & 47.4 & 25 & 43.1 & 6 & 40.0 & 3 & 37.5 \\
\hline
\end{tabular}

TABLE 2: Distribution of participants by relationship between geographical regions and answers to statements on first sexual experience

The distribution of the participants according to the answers given to the statements related to professional status and first sexual experience is seen in Table 3 . 


\section{Cureus}

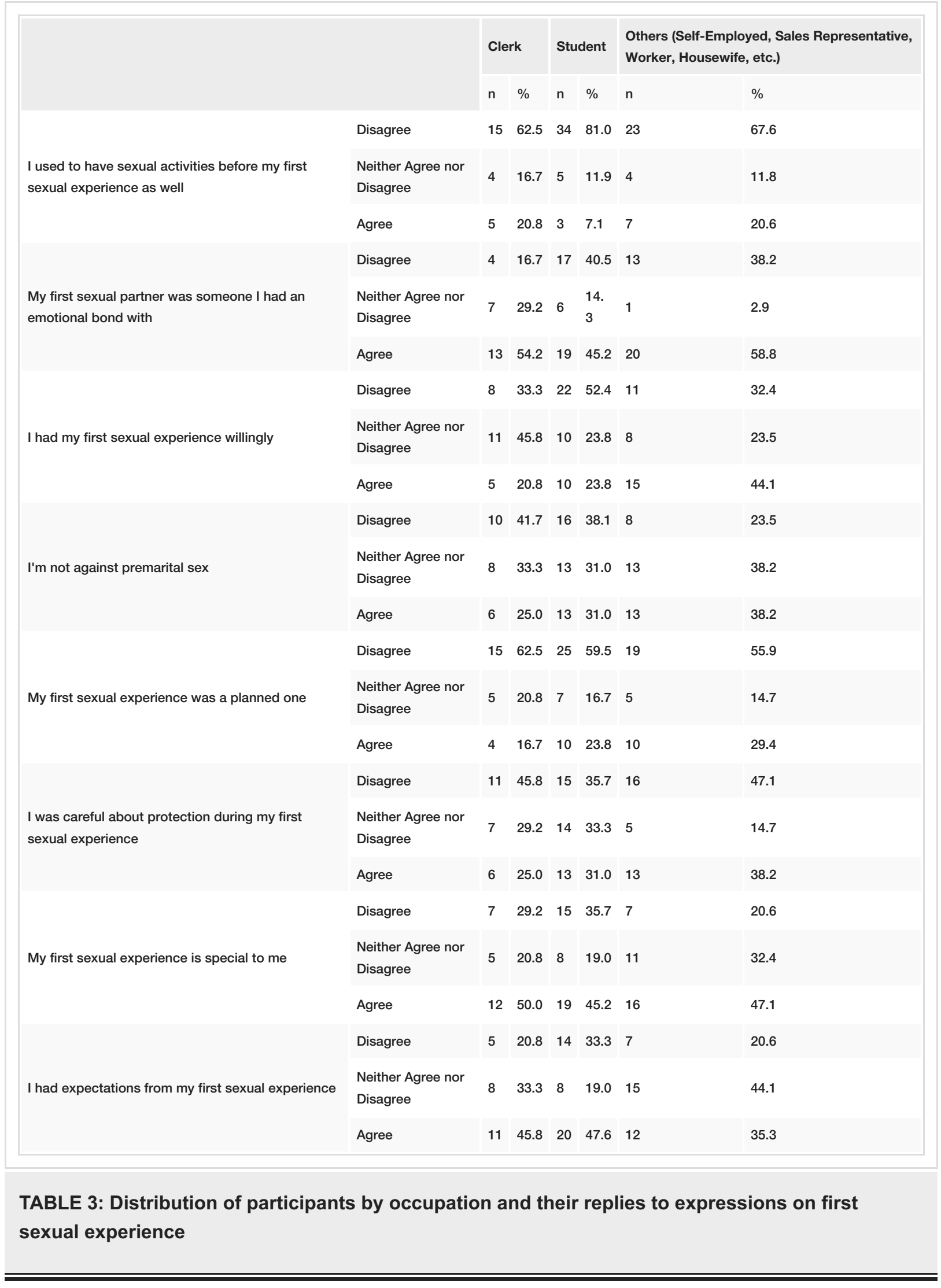

Table 4 shows the distribution of the participants according to their status of having an active sexual life and the answers given to the statements related to the first sexual experience. 


\section{Cureus}

\begin{tabular}{|c|c|c|c|c|c|}
\hline & & \multicolumn{2}{|c|}{ Yes } & \multicolumn{2}{|l|}{ No } \\
\hline & & $\mathrm{n}$ & $\%$ & $\mathrm{n}$ & $\%$ \\
\hline \multirow{3}{*}{ I used to have sexual activities before my first sexual experience as well } & Disagree & 8 & 40.0 & 64 & 80.0 \\
\hline & Neither Agree nor Disagree & 4 & 20.0 & 9 & 11.3 \\
\hline & Agree & 8 & 40.0 & 7 & 8.8 \\
\hline \multirow{3}{*}{ My first sexual partner was someone I had an emotional bond with } & Disagree & 2 & 10.0 & 32 & 40.0 \\
\hline & Neither Agree nor Disagree & 2 & 10.0 & 12 & 15.0 \\
\hline & Agree & 16 & 80.0 & 36 & 45.0 \\
\hline \multirow{3}{*}{ I had my first sexual experience willingly } & Disagree & 3 & 15.0 & 38 & 47.5 \\
\hline & Neither Agree nor Disagree & 4 & 20.0 & 25 & 31.3 \\
\hline & Agree & 13 & 65.0 & 17 & 21.3 \\
\hline \multirow{3}{*}{ I'm not against premarital sex } & Disagree & 0 & 0 & 34 & 42.5 \\
\hline & Neither Agree nor Disagree & 5 & 25.0 & 29 & 36.3 \\
\hline & Agree & 15 & 75.0 & 17 & 21.3 \\
\hline \multirow{3}{*}{ My first sexual experience was a planned one } & Disagree & 4 & 20.0 & 55 & 68.8 \\
\hline & Neither Agree nor Disagree & 5 & 25.0 & 12 & 15.0 \\
\hline & Agree & 11 & 55.0 & 13 & 16.3 \\
\hline \multirow{3}{*}{ I was careful about protection during my first sexual experience } & Disagree & 4 & 20.0 & 38 & 47.5 \\
\hline & Neither Agree nor Disagree & 4 & 20.0 & 22 & 27.5 \\
\hline & Agree & 12 & 60.0 & 20 & 25.0 \\
\hline \multirow{3}{*}{ My first sexual experience is special to me } & Disagree & 3 & 15.0 & 26 & 32.5 \\
\hline & Neither Agree nor Disagree & 3 & 15.0 & 21 & 26.3 \\
\hline & Agree & 14 & 70.0 & 33 & 41.3 \\
\hline \multirow{3}{*}{ I had expectations from my first sexual experience } & Disagree & 2 & 10.0 & 24 & 30.0 \\
\hline & Neither Agree nor Disagree & 9 & 45.0 & 22 & 27.5 \\
\hline & Agree & 9 & 45.0 & 34 & 42.5 \\
\hline
\end{tabular}

TABLE 4: Distribution of participants by active sexual life and their replies to statements on first sexual experience

The data indicates that the rate of those who are sexually active is $12.1 \%$ for the age range of $16-25$ years and $35.3 \%$ for the age range of $26-35$ years. In consequence of the chi-square analysis made, there is a statistically significant relationship between age and sexual activity $(p \leqslant 0.05)$. Thus, the rate of those who are sexually active in the age range of 26-35 years is significantly higher than those in the age range of 16-25 years.

The distribution of the participants according to the relationship between pre-marital sexual experience thinking and protection in the first sexual experience is shown in Table 5. 


\begin{tabular}{|c|c|c|c|c|c|c|c|c|}
\hline & & & \multicolumn{3}{|c|}{ I'm not against Premarital Sex } & \multirow{2}{*}{ Total } & \multirow{2}{*}{$\begin{array}{l}\text { Chi- } \\
\text { Square }\end{array}$} & \multirow{2}{*}{$\mathbf{p}$} \\
\hline & & & Disagree & $\begin{array}{l}\text { Neither Agree } \\
\text { nor Disagree }\end{array}$ & Agree & & & \\
\hline \multirow{6}{*}{$\begin{array}{l}\text { I was careful about Protection during My First } \\
\text { Sexual Experience }\end{array}$} & & Number & 21 & 10 & 11 & 42 & \multirow{7}{*}{22.742} & \multirow{7}{*}{$\begin{array}{l}0 . \\
000^{\star}\end{array}$} \\
\hline & & Percentage & $61.8_{a}$ & $29.4_{b}$ & $34.4_{\mathrm{a}, \mathrm{b}}$ & 42.0 & & \\
\hline & Neither Agree nor & Number & 12 & 10 & 4 & 26 & & \\
\hline & Disagree & Percentage & $35.3_{a}$ & $29.4 \mathrm{a}$ & $12.5 \mathrm{a}$ & 26.0 & & \\
\hline & & Number & 1 & 14 & 17 & 32 & & \\
\hline & & Percentage & $2.9 \mathrm{a}$ & $41.2 \mathrm{~b}$ & $53.1_{b}$ & 32.0 & & \\
\hline \multirow{2}{*}{ Total } & & Number & 34 & 34 & 32 & 100 & & \\
\hline & & Percentage & 100.0 & 100.0 & 100.0 & 100.0 & & \\
\hline
\end{tabular}

TABLE 5: Distribution of participants by relationship between their thoughts on premarital sex and protection in first sexual intercourse

The indices $a$ and $b$ have been used to indicate differences. There is a difference between the rates that include different letters.

*significant at $p \leq 0.05$.

\section{Discussion}

Numerous factors that organize the functions such as the individual's biological and psychological development and interpersonal relations also have a role in the commencement or continuation of sexual function disorders [8]. As is the case in numerous countries, sexuality is a difficult subject to talk about in Turkey due to numerous reasons such as social, cultural, communal, and religious ones. While evaluating the individuals' sexual functions, the evaluator learns their psychosocial, developmental, and sexual histories, and tries to access the subjects in those histories, such as the current sexual life, emotional health, relationship capacity, past experiences, development of gender identity, the first sexual experience, and traumas [9].

In their study, Ozkan and Beji evaluated the effects of the psychological and interpersonal factors on sexual function and emphasized that numerous women's emotional and behavioral reactions to their first sexual experiences were fear, anxiety, and conflict, depending on the value judgments of the society in which they live and the gender roles imposed on women by that society, and that extramarital affair is taboo in numerous societies [10]. Of the participants of this study, 47\% said, "My first sexual experience is special to me," and 52\% said, "My first sexual partner was someone I had an emotional bond with.”

In their studies, Senoglu, Coban, and Karacam emphasize that the pregnancies caused by extramarital sexual experiences can result in women paying a heavy cost [11]. Besides, the rate of unwanted pregnancies and willful miscarriages, which we encounter as a serious women's health problem in consequence of this experience, is $42 \%$ in Turkey. Besides, according to the Turkey Demographic and Health Survey Report 2013, $5 \%$ of adolescent women have given birth to children. The reasons for adolescent pregnancies and unintended pregnancies include inability in accessing contraceptive methods, failure in using them effectively and correctly, or not using the contraceptive methods at all. Society's negative and judgmental look at pregnancies caused by extramarital affairs prevents these women from receiving service from healthcare centers and filling their knowledge gaps. Women have been forced to pay a heavy cost due to their pregnancies caused by extramarital affairs. These costs can range from having a miscarriage by using traditional methods to having an abortion under inappropriate conditions, and even death. In this study, it is seen that only $2.9 \%$ of the participants who said "I'm not against premarital sex" in Table 4 also said, "I was careful about protection during my first sexual experience”. Whether those who said that they were not against premarital sex have had such an experience, on the other hand, could be the subject of another research.

At this point, it is suggested that the healthcare personnel who give information and service regarding the subjects such as sexually transmitted diseases, protection from unwanted pregnancies be trained, through on-the-job trainings at certain intervals, about the importance and dimensions of their job, given information on the sexuality matters, and enabled to offer the service they offer equally to all social 
One of the striking results of this study is the significant difference among the geographical regions. The rate of the women who live in the Black Sea region who said that they had not been careful about protection during their first sexual experience is $46.7 \%$, while $57.9 \%$ of the women who live in the Mediterranean/Aegean/Marmara region said that they had been careful about protection during their first sexual experience. At this point, it is suggested that the sexual health training to be planned should be enhanced so that it can meet the needs of the relevant geographical region as well as having special contents on the basis of the periodic features and educational background.

According to Bilgin and Kömürcü, women have a more comfortable and active sexual life with a regular partner in their adulthood period, and again in this period, they show changes regarding the social and sexual roles. They have stated that sexuality is a learnable behavior and a woman in her adulthood learns sexual behaviors and develops her ability to feel pleasure and reach orgasm [12].

Our study indicates that, in the age range of 26-35 years, those who said that they had an active sexual life are significantly higher, by $35.3 \%$, than those in the age range of $18-25$ years. Besides, our study indicates that $60 \%$ of those who had an active sexual life were careful about protection during their first sexual experiences, $65 \%$ had their first sexual experiences willingly, and $80 \%$ had their first sexual experiences with someone they were emotionally bound to. This may lead us to the conclusion that those who had their first sexual experiences willingly have been able to participate in adult sexual life actively. Besides, it is seen that $80 \%$ of those who said that they had had no sexual activity before their first sexual experience do not have active sexual life; and this shows the importance of starting the sexual education in an early period and determining its features on the basis of the periods of life.

However, whether having an active sexual life leads to displaying responsible behaviors or those who have developed responsible behaviors through education have an active sexual life and get protection against sexually transmitted diseases and unintended pregnancies, in other words, the question of which situation is the precursor of the other could be the subject of another research.

Another subject emphasized in the study of Bilgin and Kömürcü [12] is the fact that, regardless of having a sex partner, masturbation, self-satisfaction, and orgasm are important in women's getting to know sexuality, and that the women can describe sexuality as the activity performed with a partner or in various other different ways, including also masturbation. And that $15 \%$ of the women in this study said that they had had sexual activity before the first sexual experience while the fact that $72 \%$ said "no" indicates that alternative ways in getting to know sexuality may also be included in the education subject. In this way, women will be able to experience sexuality and get to know their own body and sexuality in alternative and safe ways even in an early period of their lives.

As is the case with numerous studies, the study of Bilgin and Kömürcü [12] also states sexual harassment and rape as the reason for women's sexual problems; and it has been found out that a minimum of $30-60 \%$ of women had faced sexual problem at least once in their lives.

Considering that this traumatic life started with the first sexual experience, it is possible to foresee that the potential results are more hurtful. Besides, it is emphasized that the sense of psychological commitment is more effective than estrogen and testosterone in the woman and her partner having sexual desire; and in this study, $41 \%$ of the women said that their first sexual experiences had not been a willing one [12]. However, although the experience was an unwilling one, under the influence of which factor it took place and whether there was any underlying story of harassment, rape, or abuse could be the subjects of another study.

When we look at Bahar's study "Perception of Sexuality by Generation Y", the generation Y, as used by most experts for those who were born between the years 1980 and 2001 while there are also other different definitions for the generation $\mathrm{Y}$, is the first generation that has grown up under the influence of computer and the internet and also the one that has the oldest parents compared to the other generations; and the parents of one-fourth of the generation $Y$ got college education for at least once. Generation $Y$ is a generation that has had the advantages such as fast access to information, advanced thinking, and analyzing competence. Naturally, the ways of education and information-gathering have changed for this generation, simultaneously with the change in the traditional family structure. The average age of those who have participated in this study is 24.57 years, and this plays a supportive role in reflecting the sexuality perception of generation Y, which was once called the Next Generation. In Bahar's study, when the participants were asked questions about their first relationships and first sexual experiences, four out of 24 participants said that they generally disapproved of premarital sex, and that this was unacceptable for them and their families. 20 persons regarded it as a requirement of life and a normal situation. On the other hand, the rates of those who were against, those who are not against, and those who are indecisive about premarital sex were almost equal. Of the participants, $32 \%$ said "I'm not against premarital sex" while $34 \%$ were indecisive and $34 \%$ said that they were against it [13]. 
This result indicates the transition from traditional period to the internet period in information-gathering emphasizes the importance of conveying sexuality education to individuals through different access channels. In other words, when sexuality education is made available to individuals through different access channels like the internet, TV, newspapers, and organized education, it will also be possible to educate the individuals who are the representatives of the transition era.

The rate of those who agree with the expression "I used to have sexual activities before my first sexual experience as well” is significantly different for the students compared to employees, and this rate is $81 \%$. Thus, it is possible to conclude that the most effective source to give information is organized education. It is suggested that the education given in the organized education institutions be given by the persons who are competent to give education on these subjects.

\section{Limitations of the study}

This study has some limitations. First of all, the study was run in a single center, and was carried out only under the conditions of the center where the study was conducted. The results of the study cannot be generalized. However, given the lack of studies in the literature on this issue, we believe that our results would provide a significant contribution.

\section{Conclusions}

In conclusion, sexual health education is of great importance for the women in Turkish society to develop a positive attitude towards sexuality, create a healthy and satisfactory sexual life, develop responsible and safe behaviors, and willingly without any coercion, regard sexual health as part of the general health and natural activity. This education must be planned specifically for each age, period, region, and educational background, and offered equally to all by competent persons. In the link from healthy individuals to a healthy society, sexual education must be started before the first sexual experience and continued throughout life.

\section{Additional Information}

\section{Disclosures}

Human subjects: Consent was obtained or waived by all participants in this study. Animal subjects: All authors have confirmed that this study did not involve animal subjects or tissue. Conflicts of interest: In compliance with the ICMJE uniform disclosure form, all authors declare the following: Payment/services info: All authors have declared that no financial support was received from any organization for the submitted work. Financial relationships: All authors have declared that they have no financial relationships at present or within the previous three years with any organizations that might have an interest in the submitted work. Other relationships: All authors have declared that there are no other relationships or activities that could appear to have influenced the submitted work.

\section{References}

1. Douglas JM Jr, Fenton KA: Understanding sexual health and its role in more effective prevention programs . Pub Health Rep. 2013, 128:1-4. 10.1177/00333549131282S101

2. Kalra G, Bhugra D: Sexual violence against women: Understanding cross-cultural intersections . Indian J Psychiatry. 2013, 55:244-249. 10.4103/0019-5545.117139

3. Pedersen SH, Strömwall LA: Victim blame, sexism and just-world beliefs: a cross-cultural comparison . Psychiatr Psychol Law. 2013, 20:932-941. 10.1080/13218719.2013.770715

4. Igde FA, Gul R, Igde M, Yalcin M: Abortion in Turkey: women in rural areas and the law . Br J Gen Pract. 2008, 58:370-373. 10.3399/bjgp08X280353

5. Nogueira Avelar E Silva R, Wijtzes A, van de Bongardt D, van de Looij-Jansen P, Bannink R, Raat H: Early sexual intercourse: prospective associations with adolescents physical activity and screen time. PLoS One. 2016, 11:e0158648. 10.1371/journal.pone.0158648

6. Zeren F, Gursoy E: Why sexual health education?. J DU Health Sci Inst. 2018, 8:29-33.

7. Yucesan A, Alkaya Ayaz S: A subject ignored in schools: sexual health education . Med J SDU. 2017, 25:200209.

8. Avasthi A, Grover S, Sathyanarayana Rao TS: Clinical practice guidelines for management of sexual dysfunction. Indian J Psychiatry. 2017, 59:91-115. 10.4103/0019-5545.196977

9. Kar SK, Choudhury A, Singh AP: Understanding normal development of adolescent sexuality: a bumpy ride . I Hum Reprod Sci. 2015, 8:70-74. 10.4103/0974-1208.158594

10. Ozkan Z, Beji NK: Effects of psychological and interpersonal factors on sexual function . Androl Bull. 2014, 16:203-208.

11. Şenoğlu A, Çoban A, Karaçam Z: İstenmeyen gebelikler ve isteyerek yapılan düşüklerin değerlendirilmesi. Arşiv Kaynak Tarama Dergisi. 2019, 28:300-305. 10.17827/aktd.474072

12. Bilgin Z, Kömürcü N: Kadın cinselliği ve kanıt temelli yaklaşımlar . Androloji Bülteni. 2016, 18:48-55.

13. Bahar M: Y kuşağında cinsellik algısı incelemesi: izmir örneği . Hacettepe Üniversitesi, Ankara; 2018. 